\title{
말리(Mali)분쟁: 분쟁의 이해에서 시작하는 개발
}

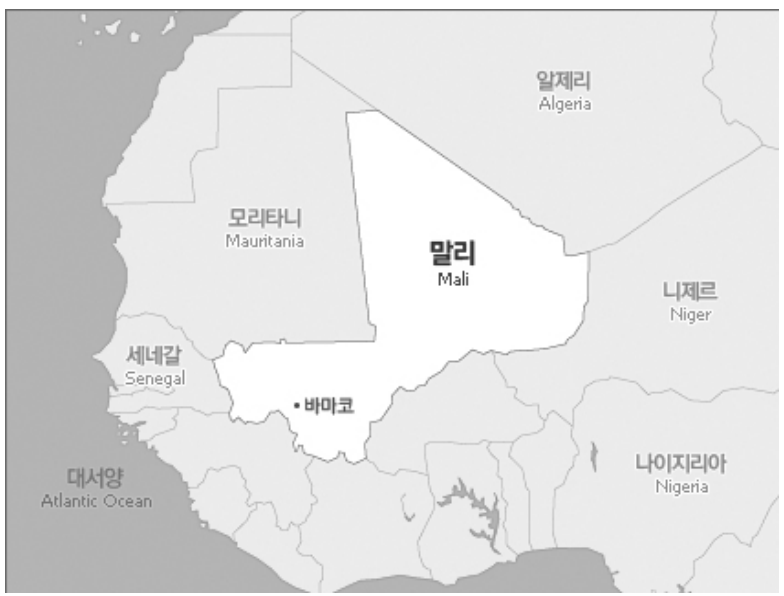

김용빈(개발마케팅연구소 소장)

목 차

I. 들어가며

II. 말리 분쟁의 원인과 경과

1. 말리 분쟁 개요

2. 분쟁의 연원과 배경

3. 말리 분쟁의 경과

4. 말리 분쟁의 원인과 전망

III. 국제사회의 지원 현황

1. 말리 지원을 위한 국제공조 체제

2. 우리나라의 Mali 지원현황

VI. 결론: 아프리카 분쟁을 대하는 개발관점의 제안 


\section{I. 들어가며}

톨스토이는 '안나 카레리나'에서 행복한 집안은 다 비슷해 보이지만, 불행한 집안 은 그 이유가 다 다르다고 말했다. 불행을 만드는 어떤 요소가 하나라도 있으면 불행 해지기 때문에 행복해지려면 모든 불행한 요소를 피해가야 한다는 통찰인데, 이는 국 가의 행복과 불행에도 적용되는 듯하다.

폴 콜리어(Paul Collier)는 2010년 저서 '빈곤의 경제학(The Bottom Billion)'에서 국 가를 빈곤에 빠트리는 덫을 네 가지로 분류했다. 분쟁의 덫, 천연자원의 덫, 나쁜 이 웃을 둔 내륙국의 덫, 작은 나라의 나쁜 통치의 덫이 그것인데 그 가운데 어느 하나 에라도 빠지면 빈곤에 직면하게 된다는 설명이다. 그런데, 이런 덫에 중복해서 빠진 다면 어떻게 될 것인가? 이를 보여주는 사례가 바로 말리(Mali)라 할 것이다.

말리는 네 개의 덫 모두에 빠져있는 국가다. 약소국이면서 허약한 거버넌스를 가졌 고, 사헬(Sahel)의 황량한 내륙에서 가난하고 호전적인 이웃국가들과 접하고 있으며, 내외부 세력과 분쟁을 겪고 있다. 식민모국 프랑스는 북부지역에 매장된 우라늄 때문 에 분쟁에 개입한다는 주장도 있으니, 천연자원의 덫에도 절반쯤은 빠져있는 듯하다. 네 가지 덫은 서로에게 원인이 되어주면서 분쟁을 불렀고, 그 분쟁이 빈곤을 심화하 는 나쁜 순환 고리에 빠져있다고 할 수 있다.

2012년 초에 발생하여 현재까지도 완전히 해결되지 않은 말리 분쟁은 현지정부의 취약한 거버넌스에 식민통치의 잔재와 민족문제, 종교적 신념 차이가 뒤섞이고 주변 국의 이해관계까지 개입되어 일개 국가 범위를 넘어서는 매우 복잡한 양상을 띠고 있다. 거기다 최근 대두하고 있는 아프리카 지역 내 분쟁해결 메커니즘과 UN시스템 이 혼재된 상태에서 프랑스의 대규모 군사개입을 촉발하였다. 이에 국제사회는 여러 측면에서 지원활동을 강화하고 있다. 특히, 개발 분야에 있어서는 보기 드물게 일치 된 활동을 보이고 있다.

신흥 공여국으로서 더욱 많은 분야에서의 기여를 국제사회로부터 요구받고 있는 우리나라는, 특수한 형태의 지원인 이라크와 아프가니스탄에 대한 지원을 제외하면, 
분쟁국 지원에 경험이 많지 않다. 말리 분쟁을 사례로 지역분쟁, 특히 아프리카 지역 분쟁의 맥락에 대해 알아보고, 분쟁국에 대한 지원 시 고려할만한 이슈를 제안해 보 고자 한다. 이를 위해 우선 1) 말리 분쟁의 원인과 경과를 분석하고, 2) 국제사회의 말리 지원현황을 공여국 회의를 중심으로 알아보고, 우리나라의 지원현황을 정리한 후, 3) 개발 분야에서 아프리카 분쟁을 대하는 관점에 대한 제안 순으로 서술하고자 한다.

\section{II. 말리 분쟁의 원인과 경과}

\section{1. 말리 분쟁 개요}

복잡한 분쟁양상을 세부적으로 분석하기 이전에 전체적인 윤곽을 파악하기 위하여 분쟁 경과를 요약하여 정리하면 아래와 같다.

2012년 초 북서 아프리카 지역 국가 Mali에서 투아레그족이 이슬람 원리주의자들 과 함께 봉기하여 북부지역을 장악하였다. 한편, 남부지역에 있는 수도 바마코에서는 청년 장교들이 쿠데타에 성공해 중앙정부 기능은 완전히 마비된다. 중앙정부가 북부 사태를 장악하지 못하자, 북부 반군들은 독립 국가를 선포하고, 대규모 난민이 발생 하는 등 혼란이 격화된다.

군부가 형식적인 민정이양을 하고 계속 정치에 간여하는 와중에, ECOWAS와 $\mathrm{AU}$ 의 아프리카 평화유지군의 파병이 늦어지면서 사태가 장기화될 조짐이 보이던 2013 년 초, 북부 세력이 남부지역과의 관문까지 진격하자 프랑스가 공습을 개시하면서 전 격적으로 개입하였다. 이후 미국과 독일 등의 공습 참가와 프랑스군의 지상군 투입으 로 북부지역 대부분은 빠르게 회복되었다.

2013년 7월부터 치안유지 임무가 프랑스군에서 UN군으로 넘겨졌으며, 이후 치러진 대선과 총선에서 선출된 민선정부가 정권을 장악하였다. 그러나 2014년 현재에도 북 부지역에서는 이슬람 무장 세력들에 의한 테러가 끊이지 않아 불안정한 상태가 지속 되고 있다. 


\section{2. 분쟁의 연원과 배경}

\section{식민주의 경계 획정에 심겨진 분쟁의 씨앗}

‘말리(Mali)'라는 국명은 1959년 세네갈-말리연방으로 독립하면서 새로 만들어진 것 이 아니다. 한때 서아프리카뿐 아니라 중근동에 이르는 넓은 세계에 널리 알려질 만 큼 번영을 누렸던 말리제국의 후신이라는 자부심으로 국호를 되찾은 것이다. 팀북투 를 수도로 했던 말리제국은 경제적으로도 부강했을 뿐 아니라, 알렉산드리아 도서관 과 비견될 정도로 장서가 많은 도서관과 아시아에서까지 찾아온 해외유학생들로 붐 비는 국가였다.

말리제국과 그 뒤를 잇던 송가이(Songhay)제국 등 많은 후신들에 의해 이어지던 전 통은 1890년 투쿨로르(Tukulor)왕국이 프랑스 식민지가 되면서 역사에서 사라진다. 물 론, 그 지역 역사상 명멸했던 많은 국가들이 현재 말리 영토와 근사한 지역을 통치한 것은 아니다. 많은 민족이동이 있었고 외침도 빈번하여 말리 민족구성은 매우 복잡하 며 1960년 세네갈-말리연방에서 따로 독립하여 현재 국체(國體)를 이루기 전에는 단 일국가로서의 정체성이 희박했다.

특히, 두 개의 삼각형을 붙여놓은 듯 보이는 나비모양 국토는 프랑스 식민주의자들 이 통치 편의상 획정한 경계를 국경으로 물려받은 것으로 주민의 민족분포를 반영하 지 못하여 독립 후에도 계속되는 분쟁의 씨앗을 제공하였다.

\section{투아레그에 대한 핍박과 불안한 동거}

투아레그(Touareg) 민족은 현재 350만 명 가량으로 추산되는, 사하라사막 일대인 알 제리, 말리, 니제르 등에 흩어져 사는 유목민족이다. 북아프리카에 사는 베르베르족과 친연관계에 있으며 언어도 베르베르어를 쓴다. 대체로 이슬람을 신봉하며 독특한 계 급사회를 이루고 있다. 말리 북부에 150 만 명 가량이 거주하고 있으며 매우 호전적인 성향으로 유명하다. 


\section{〈그림 1> 투아레그족 분포}

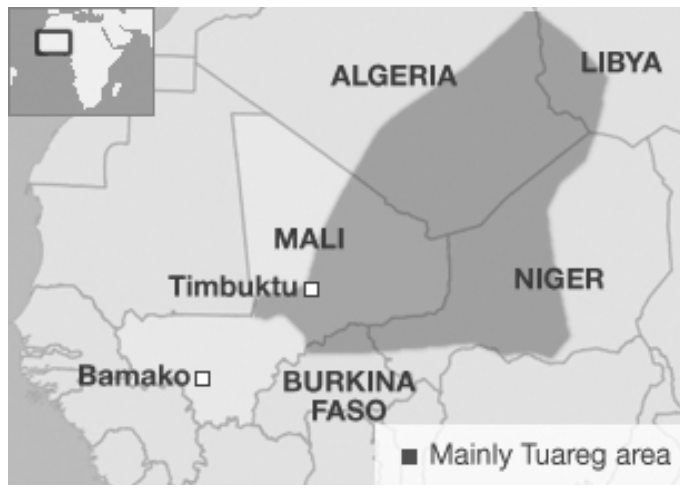

출처: www.bbc.com

이에 반해 말리 남부의 만데(Mande)족 등은 반투(Bantu)계 흑인 민족으로 니제르콩 고어족에 속하는 고유어인 밤바라(Bambara)어를 쓴다. 말리 전체 인구의 절반가량을 차지하고 있어 정치적으로 늘 다수파이다. 투아레그나 만데 외에도 많은 부족이 있으 나 전 국민의 $90 \%$ 이상이 수니파 이슬람교도이므로 종교로 인한 갈등은 없었다.

독립성이 강하고 호전적인 투아레그족은 19세기말 프랑스 식민화 과정에서 끝까지 저항하였다. 그런 저항을 맛본 프랑스는 식민통치기간 내내 투아레그족에 대해 차별 과 탄압으로 일관했다. 프랑스는 아프리카 전역에서 실시한 통치원칙 -강력한 민족은 나누고, 적대적 민족들은 한 울타리에서 경쟁시키는 원칙- 을 적용하여 식민통치 시 기 내내 투아레그족을 여러 식민지역(현재의 독립국가들)으로 나누어 통치했다. 1950 년대 말 독립을 준비하던 식민지 정치엘리트들마저 이를 계승하여 투아레그족은 확 실한 정체성에도 불구하고 독립 국가를 형성하지 못한 채 ‘아프리카의 쿠르드족'이 되어버렸다. 특히, 소수민족에 대해 정착화(sedentarization) 내지는 방관(lassez-faire)정 책을 유지하였던 이웃 리비아, 알제리 등과 달리 말리는 독립정부 수립 직후부터 식 민지 시절보다 더욱 강력한 중앙집권화 정책을 고수하면서 체제 내 편입을 거부하는 투아레그족에 대해 집요한 차별을 견지하였다. 


\section{실패의 연속이던 투아레그족의 도전}

투아레그족이 말리 중앙정부에 본격적으로 도전한 것은 2012년 초에 일어났던 사 태가 처음이 아니다. 말리 독립 직후부터 무장투쟁을 개시했고, 주변 부족들과도 이 해관계에 따라 대립하거나 협력하면서 말리 중앙정부에 대항해왔다.

1990년 말리와 니제르의 투아레그족에게 공여된 국제원조 자금을 중앙정부에서 가 로채자, 이에 대한 반발로 독립 이후 최대 규모 투쟁이 전개되었다. 이때 2012년 사 태의 주인공인 아자와드민족해방운동(MNLA)이 탄생하였으며, 말리 중앙정부는 나이 지리아군까지 끌어들여 유혈 진압에 나선다.

특히, 우라늄 확보에 열성적인 프랑스의 지원이 필수적인 말리 중앙정부는 말리 북 부에 매장된 우라늄에 대한 개발권 때문이라도 투아레그족에게 자치권조차 부여하기 를 거절하였다. 1991년 들어선 최초의 민선정부가 투아레그 반군의 말리 정규군 편 입, 북부지역 개발 등을 약속하며 평화조약을 체결하였으나, 실제로는 민족차별과 보 복이 지속되었다.

2006년 2009년까지 다시 투아레그 반군이 국지적으로 저항하였으나 열세를 면하지 못하다가 상당수가 리비아로 이동, 무아마르 카다피(Muammar Qaddafi) 정권에 의탁하 여 리비아군의 일부로 활동하였다. 2011년 '아랍의 봄' 사태에서 카다피의 사병(私兵) 으로 활동하던 투아레그 반군이 상당한 군자금과 무장을 보유한 채로 말리 북부로 귀환, 독립을 위한 무장투쟁에 들어간다.

\section{겉보기에는 민주적이지만 허약한 거버넌스의 말리 정부}

한편, 독립 이후 1968년부터 1991년까지 줄곧 군사독재를 펼치던 트라오레(Traore) 가 군부에 의해 축출되고 선거를 통해 민간에 평화적으로 정권을 이양하여, 아프리카 에서는 보기 드문 민주주의가 수립되었다. 이 때 군부 지도자 아마두 투마니 투레 (Amadou Toumani Toure)는 ATT라는 애칭으로 불리며 국민적 영웅으로 부상하였다. 
1992년 자유민주선거를 통해 취임한 코나레(Alpha Oumar Konare) 대통령은 민주주 의 정착, 인권상황 개선, 시장경제의 도입, 규제철폐 및 적극적인 원조확보 등을 통한 경제개발에 노력하여 1997년 재선에 성공하였으며, 2002년 대선에서도 중립을 유지하 여 ‘민주적이고 평화적인 말리’라는 국가 이미지를 창출하였다.

2002년 대선에서 1991년의 군부지도자인 Toure가 무소속으로 출마, 대통령에 당선 되었으며, 3 개 주요 정당으로 연정을 구성하여 국제사회에서 상당히 높은 평가를 받 아왔다. Good Governance 측면에서 상당한 진전을 달성한 것으로 평가받았고, 2007년 재선에도 성공한다.

그러나 외부에 보이는 정치적 민주화의 내면에는 투아레그족 등 북부 소수민족들 에 대한 차별, 뿌리 깊은 부정부패와 무능이 도사리고 있었으며, 이런 약점이 2011년 투아레그 반군의 저항과 맞물린 쿠데타로 드러난다.

\section{계획되지 않은 쿠데타와 무력한 대응}

2009년 이후 잠잠하던 투아레그 반군 세력은 2011년 말 리비아에서 동족들이 중무 장한 채 귀환하자 2012년 1월 북부에서 독립을 선언하고, 당황한 말리 중앙정부는 급 히 진압군을 투입한다. 그러나 과거와는 확연히 달라진 투아레그 반군 앞에 선 말리 군은 무장 수준과 병참 면에서 열세를 면치 못하고 패퇴한다.

수도 바마코(Bamako)에 돌아온 패잔병들은 중앙정부의 무능을 성토하는 시위를 시 작했고, 이 시위가 변질되면서 2012년 3월 23일 아마두 사노고(Amadou Sanogo) 대위 가 쿠데타를 일으켜 투레 대통령을 축출하고 '민주회복국가평의회' 의장직을 맡아 국 가원수로 나섰다. 4월에 그는 디온쿤다 트라오레(Dioncounda Traoré) 국회의장에게 대 통령 대행직을 맡기고 공식적으로 퇴임하였으나 현재까지 계속해서 정치에 영향력을 행사하고 있다.

다행히 2013년 8월 실시된 대선에서 총리를 역임한 바 있는 이브라힘 케이타 (Ibrahim Keita) 후보가 당선되었다. 


\section{3. 말리 분쟁의 경과}

\section{목표가 제각각인 '반군'의 구분}

말리 분쟁은 전형적인 아프리카 분쟁 즉, 민족 간 정치 헤게모니 경쟁과 이슬람 종 파 간 노선갈등이 혼합된 위에 국가보다 상위 개념인 지역(Region) 차원의 외부세력 과의 연대 등이 혼재하는 복잡한 양상을 보인다. 따라서 분쟁에 참여하고 있는 당사 자를 구분하고 당사자 간 관계를 정리해야 이해하기가 쉽다.

말리에서 '반군'이라 통칭되는 세력은 아래와 같이 대략 4개의 집단으로 나뉘며, 그림 2에서 보는 바와 같이 노선에 따라 연대와 갈등을 겪고 있다.

- 아자와드민족해방운동(MNLA, Mouvement National pour la Liberation de l'Azaward)

말리 독립 직후부터 투아레그 독립운동의 중심인 조직. '아자와드' 북부 3 개주의 통칭이다. 카다피 통치시기 리비아군에 용병부대격으로 속해있던 말리 투아렉 국가연 맹(l'Alliance Nationale des Touaregs Mali)이 카다피 사후 리비아를 이탈, 2012년 독립 을 선언하였다. 민족주의 성향이 강하여 투아레그 국가건설을 목표로 한다.

\section{- 안사르딘(Ançar Dine)}

MNLA 내부 권력투쟁 과정에서 분파된 조직으로 안사르 앗딘(Ançar Ad-dine, '종교 의 수호자'란 뜻)이라고도 하며 샤리아(Sharia)에 근거한 이슬람 국가 건설을 목표로 한다. 안사르 앗딘은 극단주의 이슬람 세력보다는 온건 이슬람주의에 가까워 MNLA 와 노선차이에도 불구하고 독립국가 건설 투쟁에서는 연대하고 있다. 
- 이슬람 마그레브 알카에다(AQMI, Al-Qaida au Maghreb Islamique)

오사마 빈라덴(Osama bin Laden) 사후 북아프리카 지역, 특히 알제리를 중심으로 기존에 활동 중이던 원리주의 무장 세력인 '예언과 투쟁을 위한 살라피스트 조직 (GSPC: Groupe Salafiste pour la Prédication et le Combat)'에 뿌리를 두고 자생적으로 형성된 알카에다의 분파 조직이다. 아랍계가 주축으로 매우 극단적인 노선을 취하고 있으며, 사헬(Sahel) 지역 내 대부분의 지역 이슬람 무장 세력들과 연대하고 있다.

- 서아프리카 지하드 통일운동(MUJAO, Mouvement pour la l'Unicité et le Jihad en

2011년 중반 AQMI에서 분파하여 형성된 가장 폭력성이 강하고 극단적 노선을 취 하는 이슬람 무장 세력으로, 서아프리카 전역에 성전(聖戰, Jihad)을 전파하는 것 목표 로 한다. 아프리카 흑인계가 주축이다. 이 점에서 국가 건설을 목표로 하는 MNLA나 안사르딘과 노선이 크게 다르며, 북아프리카 일대 이슬람 원리주의 세력들과 협조관 계를 유지하고 있다. 서구인에 대한 납치, 살인 사건 대부분을 자행한 집단인 것으로 도 유명하다.

<그림 2> 말리 분쟁의 주요 당사자
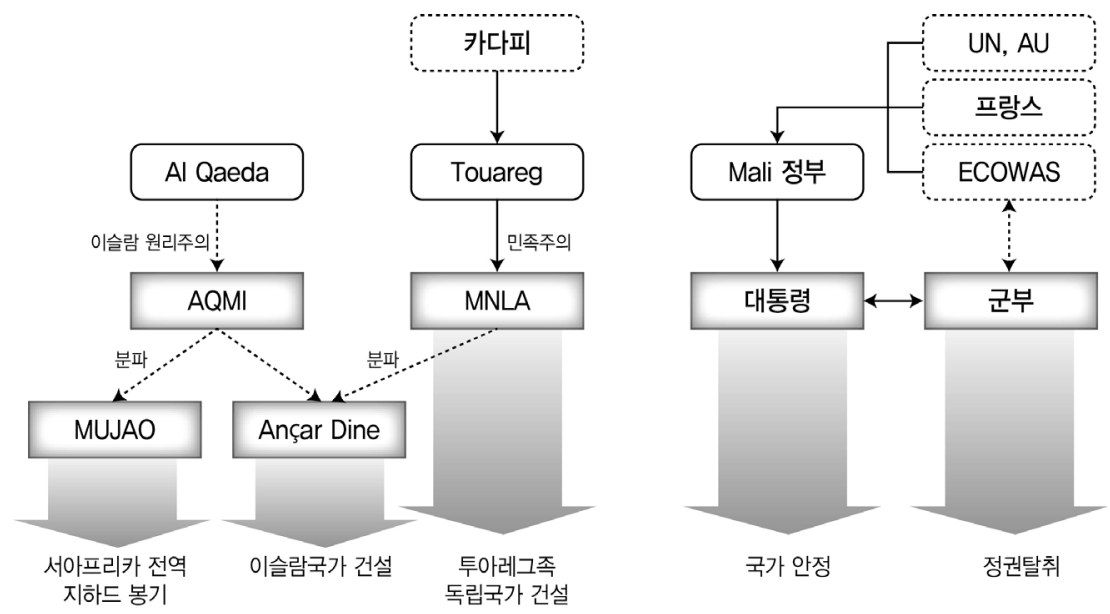

출처: 저자 작성 
위의 주요 세력 외에도 북부 말리에서 거점지역별로, 또는 완전독립이나 자치 가운 데 추구하는 노선별로, 폭력성의 정도별로 아래와 같이 여러 무장 세력이 할거 하고 있다.

- HCUA(Haut Conseil pour l'Unite de l'Azawad)

- MAA(Mouvement Aabe de l'Azawad)

- CPA(Coalition du Peuple pour l'Azawad)

- CMPFR(Coordination des Mouvements et Fronts Patriotiques de Résistance)

반군에 비해 말리 정부 측은 합법적으로 선출된 대통령과 군부가 대립, 갈등하는 것을 제외하면 이해가 어렵지 않다. $\mathrm{UN}, \mathrm{AU}$, 서아프리카경제공동체(ECOWAS)는 프 랑스에 크게 의지하고 있으며, 정부 측 외부세력은 군부에서 정치적 성격을 배제하고 통제범위 안으로 끌어들이려 노력하고 있으나 쉽지 않다.

\section{2년 말리 사태의 경과}

2012년 1월 MNLA가 북부를 본격적으로 점령하기 시작하자 $\mathrm{UN}$ 추산 20만여 명의 시민들이 알제리, 니제르, 모리타니아 등지로 피난을 떠나기 시작하였다. 3월에는 수 도에서 쿠데타가 발생하는 동안 MNLA가 키달, 팀북투, 가오 등의 주요 도시들을 장 악하고, 4월에는 북동부 말리가 투아레그족의 독립국가임을 선언하였다. 이에 알제리, 모리타니아, 니제르 등 인근 국가들은 국가인정을 거부하고 ECOWAS는 군사개입을 천명하였다. 


\section{<그림 3> 반군 장악지역(2012.4.기준)}

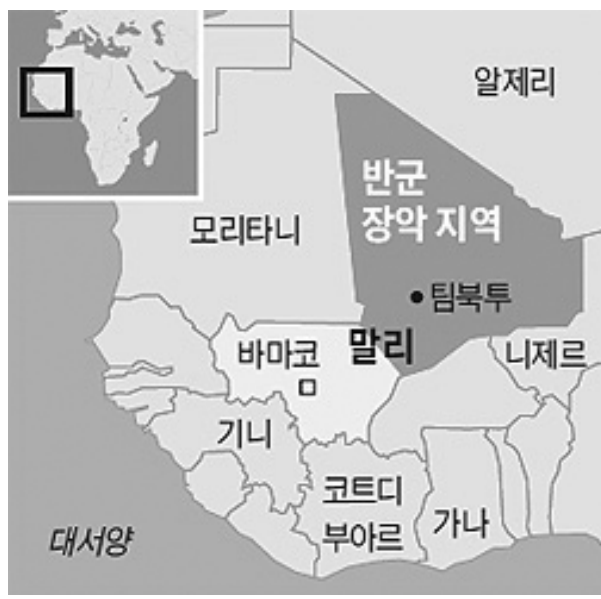

출처: http://news.chosun.com/

ECOWAS와 UN이 2012년 10월과 12월에 각각 파병결의안을 의결했으나 실제 파병 이 늦어지다가 2013년 1월 MNLA가 남부로 진격하자 프랑스가 바로 공습을 개시하 였다. 약 3주 만에 프랑스군이 북부 대부분을 회복했으나 UN군 파병이 늦어져 2013 년 7월에야 UN말리안정화임무단(MINUSMA, Mission Intégrée des Nations Unies pour la Stabilisation au Mali)에게 지역통제를 맡길 수 있었다.

그 뒤로도 국지적 충돌이 현재까지 산발적으로 일어나고 있으며, 주변국들의 적극 적인 중재로 2014년 5월에는 MNLA, HCUA, MAA 등이 정전 합의에 서명하고, 6월 에는 모든 정파 간 포괄적인 대화에 참여할 것을 약속하는 '알제 선언(Declaration d'Alger)'에 서명하였다. 한편, MINUSMA 임무가 2014년 6월로써 종료될 예정이었으 나, 새로운 상황이 전개됨에 따라 유엔안보리는 MINUSMA의 임무연장 결의를 채택 하였다.

하지만, 말리 북부는 현재까지도 산발적인 테러가 끊임없이 일어나고 있다. 


\section{4. 말리 분쟁의 원인과 전망}

\section{말리 분쟁의 원인 정리}

말리 사태의 원인은 크게 근본적인 원인과 직접적인 원인, 두 가지로 나눠서 봐야 하며 직접 원인은 다시 외부요인과 내부 요인으로 나뉜다.

근본적인 원인은 역시 투아레그족 문제이다.

프랑스 식민지시절부터 시작된 투아레그 탄압은 독립 후 말리 정부에서 더욱 강화 되는 경향이 있었으며, 이웃한 알제리, 리비아, 니제르 등에서의 포용정책과 대비되어 말리 투아레그족에게 지속적인 자극이 되었다. 정치적인 소외 외에도 경제적인 고립 과 빈곤은 투아레그족을 투쟁일변도로 몰아세운 주요 원인이 되었다.

직접적인 외부요인은 리비아에서 카다피 정권이 붕괴하며 재정적, 군사적으로 강화 된 투아레그족을 통제하지 못하게 된 것과, 오사마 빈 라덴 사후 분열되어 각 지역에 서 알카에다 산하 조직이 발호하게 된 것을 들 수 있다. 노선에 따라 여러 조직으로 분열된 것이 통일된 무장 세력으로서 강력한 무력을 행사하지 못하는 것은 다행스런 일면이나, 분쟁해결을 위한 노력에는 당사자가 많은 것이 절대적으로 불리한 상황이다.

직접적인 내부요인은 말리 정부의 취약한 Governance이다. 국제사회가 말리 정부가 보여주는 평화적 정권교체 과정에 도취되어 있는 동안, 말리 사회는 부정부패와 무책 임과 무능에 깊이 찌들어버렸다. 국가 내부반란에 속수무책으로 예전 식민모국인 프 랑스에게 구조요청을 하고, 공습을 마친 올랑드 대통령의 방문을 전 국민이 환영하는 모습, 그리고 북부 반군과의 평화협정을 이끌어 나가지 못하는 무기력한 정부를 혁신 하는 것이 절체절명의 과제인 이유다. 


\section{말리 사태의 전망}

말리 사태는 단기간에 종식되지 않을 전망이다.

원인 분석에서 볼 수 있는 것처럼 말리 분쟁은 연원이 깊고 당사자가 많다. 또, 분 쟁의 원인이 된 여러 가지 문제 가운데 어떤 것 하나도 아직까지 해결하지 못한 상 태다.

투아레그족에 대해 독립을 부여, 주권국가로 인정하는 것은 주변국의 이해관계에 반 하는 것이므로 어렵다고 해도, 광범위한 자치를 인정해 안정화를 도모해야 하는데, 북 부 지역이 말리 영토의 $60 \%$ 나 차지하는 점과 북부에 투아레그족 외에도 이해관계가 다른 여러 민족이 혼재되어 있다는 점 등을 고려할 때 이 역시 쉬운 선택이 아니다.

투아레그족에 대한 경제적 지원은 가장 근본적인 분쟁 해결책 가운데 하나이지만, 말리 중앙정부를 위협하는 일이 될 수도 있기에 역시 선택하기 쉽지 않은 딜레마가 된다.

$\mathrm{AQMI}$ 등 이슬람 원리주의 무장 세력과 그 영향을 받은 세력들의 계속되는 침투와 발호를 막는 것 역시 어려운 과제다. 말리 분쟁이 발발한 이후 이라크와 시리아를 배 경으로 IS(Islam State)가 태어났고, 국제사회는 뾰족한 방법을 못 찾고 있다. 북서 아 프리카 일대의 이슬람 세력들에게 IS는 하나의 역할모델을 제시하고 있으며, 그들의 일정한 성공에 고무되어 있다.

말리 중앙정부가 가진 무능과 부패도 쉽게 고쳐질 것 같지 않다. 말리 정부는 국제 사회의 원조에 절대적으로 의존하면서도 2014년 6월 4천만 불을 들여 대통령 전용기 를 구매한바 있다. 이에 대해 IMF는 3 억불의 자금집행을 유예하고, 세계은행과 $\mathrm{EU}$ 역 시 각각 6 천 3 백만 불 및 1 억 유로 규모의 원조를 잠정 동결하겠다고 발표한 바 있다. 


\section{III. 국제사회의 지원 현황}

\section{1. 말리 지원을 위한 국제공조 체제}

말리 분쟁에 대한 국제사회의 지원은 개별 국가별 지원을 넘어서 국제공조 체제하 에서 강력하게 조정되는 특징을 가진다. 물론, 특수한 이해관계자인 프랑스가 $\mathrm{EU}$ 를 통하여 많은 역할을 하는 속성을 가지기는 하지만, 이는 국제사회가 분쟁 회복을 위 한 지원에서 진일보한 모습을 보이는 것으로 평가할 수 있다.

구체적으로 국제사회는 말리 재건을 지원하기 위해 2013년 5월 '말리 공여국 회의 (Donor Conference for Development in Mali)'를 만들었다. 회의는 프랑스 정부, EU 집 행위, 말리 과도정부가 공동으로 주최하며 우리나라를 포함한 108 개국이 참여한다. 우리나라는 이 회의에 참석하여 1 백만 불을 공여하기로 하였다.

이 공여국 회의는 말리 정부가 마련한 자체 개발전략에 대한 국제사회의 지원 방 안을 논의하는 자리인데, 2013년 5월 회의에서 말리 정부는 PRED 2013 2014(Plan pour la Relance Durable du Mali)를 공여국 회의에 제출했다. 이 회의는 말리 정부가 요청한 20 억 유로를 훨씬 상회하는 32억 8천만 유로(4조 6750 억 원)를 공여하기로 결 의했다. 이 가운데 $\mathrm{EU}$ 는 10 억 유로, 독일이 1 억 유로를 부담한다.

주로 특정 수원국에 대한 Harmonization을 다루는 지금까지의 공여국 회의들과는 달리, 말리 공여국 회의는 2013년 5월 결의를 이행하기 위한 후속회의(International Follow-Up Meeting of Donor Conference for Development in Mali)를 계속 열고 있으며, 현재까지 4차에 걸쳐 열렸다. 각 후속회의 내용은 아래와 같다.

\section{1차 후속회의(2013년 11월, 말리 바마코)}

6개월 만에 모인 다시 모인 공여국들은 이미 결의된 금액 가운데 304 백만 유로가 구체적으로 약정되었으며, 125 백만 유로는 선거관리를 위한 일반재정지원으로 이미 지출된 것을 확인했다. 
말리 정부는 향후 우선순위 사업으로서 사법개혁(12백만 유로), 분쟁방지 프로그램 (5백만 유로), 수도 바마코 - 북구 팀북투간 $565 \mathrm{~km}$ 도로 재건(32백만 유로 추가) 등에 지원을 요청하였다.

EU는 2014 2020년간 말리의 국가혁신, 식량안보, 교육 등 분야와 북부 주요도시인 가오, 키달 지방과 알제리를 연결하는 도로 개설 사업 등에 615 백만 유로를 지원하기 로 하였다.

- 공여국들은 말리 정부에 아래 사항을 당부하였다.

- 법치 확립과 국제수준의 선거관리

- 기본적인 복지서비스 재개를 위한 전국적 국가기관 기능 회복

- 공공질서 회복과 민간인 보호를 위한 민간기구 활동 지원

- 난민과 기아위기에 처한 주민들에 대한 인도적 지원

- 국가기구의 중장기 발전을 위한 노력

\section{2차 후속회의(2014년 2월, 브뤼셀)}

최초 결의되었던 32 억 8 천만 유로 중 이미 $74 \%$ 가 구체적으로 약정되고, $1 / 3$ 가량 이 이미 집행되는 등 공여국들은 적극적인 약속 이행을 높게 자평하였다.

공여국들은 말리 정부에게 공공재정 개선, 지방분권, 사법개혁, 부패 근절 이행 노 력을 보다 가속해 나가기를 당부하면서, 북부지역 안정화를 위한 포괄적인 파트너십, 지속가능한 회복을 위한 친기업환경 구축, 민간부문과의 협력의 중요성을 강조하였다.

$\mathrm{EU}$ 는 결의한 원조금액 523 백만 유로의 $50 \%$ 가량인 238 백만 유로를 이미 집행하였 으며, 집행한 지원금액 중 $50 \%(120$ 백만 유로)를 말리 정부예산으로 직접 투입하였다 고 밝혔다.

2013년까지는 인도적 지원이 대부분을 차지하였으나 2014년부터는 경제회복과 지 속가능한 성장으로 중점을 이동할 예정이며, 2014년에는 정부에 대한 직접 예산지원 
비율도 더 높아질 것으로 전망했다. 이와 관련, 공여국들은 말리 정부의 수용 능력 (absorption capacity)의 중요성을 언급하며, 정부조달 및 공공재정시스템 개선을 위한 노력이 병행되어야한다고 강조했다.

말리 정부는 경제회복과 지속가능한 성장을 위해서는 일자리 창출에 큰 잠재력을 가진 농업분야 발전에 중점을 두고 있다고 설명하면서, 자영농 지원 프로그램 및 농 업 클러스터(Agro-cluster) 등을 추진 중이라고 밝혔다. 다만, 농업발전을 위한 인프라 부족, 1 차 산품 가격변동에 취약한 monoculture 경제구조, 부실한 농산업 기반 및 불 분명한 토지소유권 제도 등 현실적인 장애가 있음을 시인하기도 하였다.

또한, 민간부문과의 협력, 기업환경 개선 등을 위해 2014-2015년간 정부차원의 창 업지원, 금융접근성 개선, 민관협력사업(PPP) 등을 추진할 것이라고 설명하였다.

\section{3 차 후속회의(2014년 5 월, 말리 바마코)}

공여국들과 말리 정부는 식수, 교육, 국가화해, 북부지역에서의 행정력 복원 등과 같이 말리 정부의 당면과제에 대해 논의하였다.

공여국들은 2013년 5월 브뤼셀회의 이후 1년간 말리 정부가 취해온 조치와 성과 에 대해 대체적으로 만족감을 표시하면서도, 말리의 지속가능한 발전 및 항구적 평화 정착을 위해 해결해야할 과제들이 아직 산적해 있음을 지적하였다.

대부분의 공여국들은 말리 정부에 대해 반군세력과의 포괄적 대화 강화, 부정부패 척결, 재정투명성 제고를 위해 더욱 노력해 줄 것을 요구하였다.

\section{4차 후속회의(2014년 9월, 브뤼셀)}

말리 정부는 Good Governance, 고용, 직업훈련 및 기업활동 환경개선 등에 대한 현 황을 보고하고, 공여국들은 알제리 정부의 지원 하에 북부 반군과 협상중인 국가화해 에 대해서 논의하였다. 


\section{말리 공여국 회의의 한계}

1 차 후속회의에서와 달리 2차 후속회의부터는 미국과 중국이 모두 참여하지 않는 등 말리에 대해 이해관계가 많은 $\mathrm{EU}$, 특히 프랑스 중심의 유럽-아프리카 회의체라는 한계가 지적되고 있다. 회의체의 프랑스에 대한 과도한 의존은 프랑스 국내 정치지형 변화가 말리 상황에 즉각 반영되거나, 프랑스의 독주를 의식한 다른 공여국들이 소극 적으로 참여하는 부작용이 있다는 비판도 있다.

또한, 말리가 속한 사헬(Sahel) 지역 내에서 빈곤을 겪고 있는 여러 인접국들에 비 하여 정치적으로 불안한 말리가 국제사회로부터 집중적인 지원을 받는 것은 분쟁이 있는 곳에 더욱 많은 원조가 주어진다는 그릇된 인식을 줄 여지가 있다.

가장 중요한 문제는 원조 공여국 회의가 말리 정부의 무능과 부패 행태를 근본적 으로 뜯어고칠 수는 없다는 것이다. 지금까지 4차에 걸친 후속회의에서 공여국들은 지속적으로 말리 정부의 부정부패 척결, 재정투명성 제고, 행정효율성 강화 등을 주 문해 왔다. 그러나 재정의 대부분을 원조에 의존하고 있는 말리 정부는 원조의 일반 재정지원 비율을 높여달라고 요구하면서도 불투명한 조달절차를 그대로 두고 불필요 한 구매를 계속하여 공여국들의 비난을 받고 있다.

이러한 문제제기에도 불구하고, 말리 공여국 회의는 아프리카의 특정 분쟁에 대해 국제사회가 보여주던 무관심과 무질서한 원조 양상을 탈피하였다는 점, 물리적인 평 화의 정착과 민주정치 유지에 상당한 기여를 하고 있다는 점 등에서 우호적인 평가 를 받고 있다.

\section{2. 우리나라의 Mali 지원현황}

우리나라에서 Mali에 공여한 원조는 최근까지 매우 제한적이었으며, 1.8 백만 불의 무상지원과 61.23백만 불의 유상지원(승인기준)이 전부이다. 유상 지원되는 프로젝트 지원은 최근에야 이루어져 수행과정에서 분쟁의 영향을 받고 있다. 


\section{무상지원}

$\mathrm{KOICA}$ 의 무상지원 내역은 아래 표 1 에서 보는 바와 같다. 물자지원 및 연수생 초 청은 주로 행정 분야 지원을 중심으로 이뤄졌고, 우리 공관 및 $\mathrm{KOICA}$ 사무소가 없 어 적극적인 지원이 없다가 최근에는 $\mathrm{NGO}$ 활동을 지원하는 방향으로 이뤄졌다.

<표 1> 말리에 대한 KOICA 무상지원 내역 (1991 2012)

\begin{tabular}{c|c|c|c}
\hline 구 분 & 실 적 & 지원금액(천불) & 비 고 \\
\hline 물자지원 & 12건 & 803 & 2005년까지만. 주로 자동차 \\
\hline 연수생 초청 & 27개 과정 33명 & 176 & 행정 분야 위주 \\
\hline 해외봉사단 & 1명 & 16 & \\
\hline $\mathrm{NGO}$ & 3개 기관 & 803 & \\
\hline 합 계 & & 1,798 & \\
\hline
\end{tabular}

출처: stat.koica.go.kr 자료로 저자 정리

무상지원 사업 가운데 $\mathrm{NGO}$ 지원사업은 표 2와 같이 주로 아동 교육 및 식수 등 보건환경 개선사업을 지원하였다

<표 2> 말리에 대한 $\mathrm{KOICA}$ 의 $\mathrm{NGO}$ 지원사업

\begin{tabular}{c|c|c|c}
\hline 연도 & NGO & 사업내용 & $\begin{array}{c}\text { 지원금액 } \\
\text { (백만원) }\end{array}$ \\
\hline 2008 & 세이브더칠드런 & 5세미만 영유아를 위한 보건의료 서비스 & 296 \\
\hline $2011 ~ 2012$ & 플랜한국위원회 & $\begin{array}{c}\text { 미취학 아동교육 지원 및 } \\
\text { 지역사회 식수지원 }\end{array}$ & 434 \\
\hline 2011 & 월드비전 & $\begin{array}{c}\text { 방카스 지역 취약계층을 위한 } \\
\text { 식수위생 개선 }\end{array}$ & 165 \\
\hline 합계 & 3개 기관 & & 895 \\
\hline
\end{tabular}

출처: stat.koica.go.kr 자료로 저자 정리 


\section{유상지원}

$\mathrm{EDCF}$ 지원은 2009년에 승인된 2건 총 61.23백만 불로 그 내용은 아래 표3과 같다.

<표 3> 말리에 대한 EDCF 승인 사업내용

\begin{tabular}{|c|c|c|}
\hline 승인연도 & 사업내용 & $\begin{array}{c}\text { 승인액 } \\
\text { (백만불) }\end{array}$ \\
\hline 2009 & $\begin{array}{l}\text { 정부행정망 구축사업 } \\
\text { : 행정관청간 기간망 구축, 지선 연결, 우체국 현대화, } \\
\text { 교육훈련, 운영 및 관리 }\end{array}$ & 39.65 \\
\hline 2009 & $\begin{array}{l}\text { 관개개발사업 } \\
\text { : 관개시설 건설, 농지 및 양식장 및 목초지 개발 } \\
\text { (EDCF는 전기기계설비만 지원) } \\
\text { ※ AfDB, WB와 협조융자 사업, 전체 사업규모는 248.7백만불 }\end{array}$ & 21.58 \\
\hline 합 계 & 2 건 & 61.23 \\
\hline
\end{tabular}

출처: $\mathrm{EDCF}$ 자료로 저자 정리

정부행정망 사업은 2011년 12월 차관계약이 발효되고 구매계약이 체결되었으나, 2012년 3월 쿠데타 발생으로 현장실사가 지연되고 한국 측 인력이 철수하였다. 2012 년 8월에는 ECOWAS 군대의 수도 주둔으로 현장실사를 재개하였으나, 이후 정세 불 안으로 2013년 6월까지 설계 작업만 수행하였다. 2013년 9월 착공하였으나 전체적으 로 13년 12월에 준공예정이던 사업이 2015년 5월로 준공이 늦어지면서 사업기간이 1 년 6개월 늘어나게 되었다.

일반적으로 1 년 6 개월 정도의 장기간 공기지연은 시공업체에 큰 간접비 부담을 주 나, 별도 증액은 고려되지 않았다.

사업내용 가운데 전국에 흩어진 우체국망(우정망) 78 개소가 있는바, 내전 직접 영 향권에 들어 있는 현장은 한국인이 아닌 현지인 계약자를 교육해 투입하는 방식으로 진행하려고 현지 당국과 협의 중이다. 
관개개발 사업은 $\mathrm{AfDB}, \mathrm{WB}$ 등과의 협조융자 사업으로 정부행정망 사업과 동일자 로 차관계약이 발효하였다. 그러나 parallel 방식 협조융자 사업임에도 사업실시의 통 일성 및 일관성을 위해 $\mathrm{AfDB}$ 자금으로 사업실시지역 당 1 명씩, 총 3 명의 컨설턴트를 고용하는 등 전체 프로젝트 차원의 구매활동이 늦어지면서 $\mathrm{EDCF}$ 구매도 늦어져 2014년 내에 입찰이 열릴 예정이다.

그 밖에도 원조와 외국인직접투자를 연계한 원당(原糖)공장 사업이 $\mathrm{EDCF}$ 가 참여하 는 협조융자 사업으로 추진되어 왔으나, 내전 발발로 외국인 투자자가 투자계획을 철 회하면서 사업추진이 무산되었다.

\section{VI. 결론: 아프리카 분쟁을 대하는 개발관점의 제안}

\section{개별 국가를 넘어선 '지역'에 대한 관심}

아프리카 분쟁이 가지는 특징 가운데 하나는 분쟁 지역이 국내에만 한정되는 경우 가 별로 없다는 것이다. 국경과 민족분포가 관련이 없거나 심지어 분쟁을 조장하는 방향으로 경계가 획정된 역사적 이유 외에도, 국경을 넘어선 정치엘리트 간의 합종연 횡과 패권의식을 가진 군사독재자들로 인해서, 또 국경을 넘어서 종교적 신념을 관철 하려는 원리주의자들의 대두로 국내 분쟁으로 시작된 많은 분쟁들이 결국 국제적 분 쟁으로 비화하는 경우가 많다.

말리 분쟁의 경우에도 주변국들이 민족과 종파적 신념, 정치적 이해관계에 따라 여 러 가지 각도에서 분쟁에 개입하고 있다. 분쟁 원인과 그 여파를 주변국들이 공유하 고 있는 것이다. 그래서 그림 4에서 보는 미국의 예처럼 말리에 대한 지원을 '사헬' 이라는 지역적 관점에서 분석하고 대응할 필요가 있다. 


\section{<그림 4> 사헬(Sahel) 지역 내 미국의 인도적 지원활동}

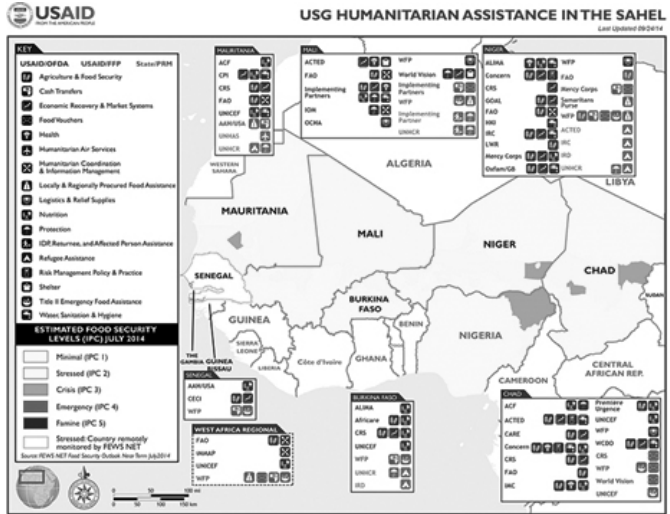

출처: http://www.usaid.gov/crisis/mali

그러나 우리 상황은 어떠한가? 중동이나 중앙아시아의 경우와는 달리 아프리카에 관해서는 분쟁에 대한 분석단위가 국가를 넘어서지 못하고 있다. 물론, 아프리카에 대해서는 국가 단위의 정밀한 분석도 귀한 형편이지만, 지금부터라도 '지역' 차원으 로 분석의 범위를 넓히고 깊이를 더하는 조치가 필요하다.

분쟁에 대해 깊이 모르고서는 분쟁국에 대한 지원에 자신 있게 나설 수가 없다.

\section{분쟁국에 대한 차별화된 지원}

권혁주 외(2010)는 취약국에 대한 $\mathrm{KOICA}$ 의 지원 분야를 교육(약 $23 \%$ ), 보건의료 (약 $21 \%$ ), 정보통신(약 $17 \%$ ) 순으로 분석했다. 또한, 이것이 KOICA가 여러 가지 취 약성 요소 가운데 국가행정능력 향상에 집중적으로 지원하고 있음을 보여주는 바, 취 약국의 행정능력 향상에 과도하게 집중하면 원조효과성이 저해될 수 있다고 지적하 고, 취약국에 대한 $\mathrm{KOICA}$ 의 원조효과성을 높이기 위해서는 수원국의 다양한 취약성 구조에 적절히 대응할 수 있는 차별적 지원전략을 펼칠 것을 제안했다. 
<그림 5> KOICA 전체 지원사업 및 취약국 지원사업의 분야별 비중(\%)

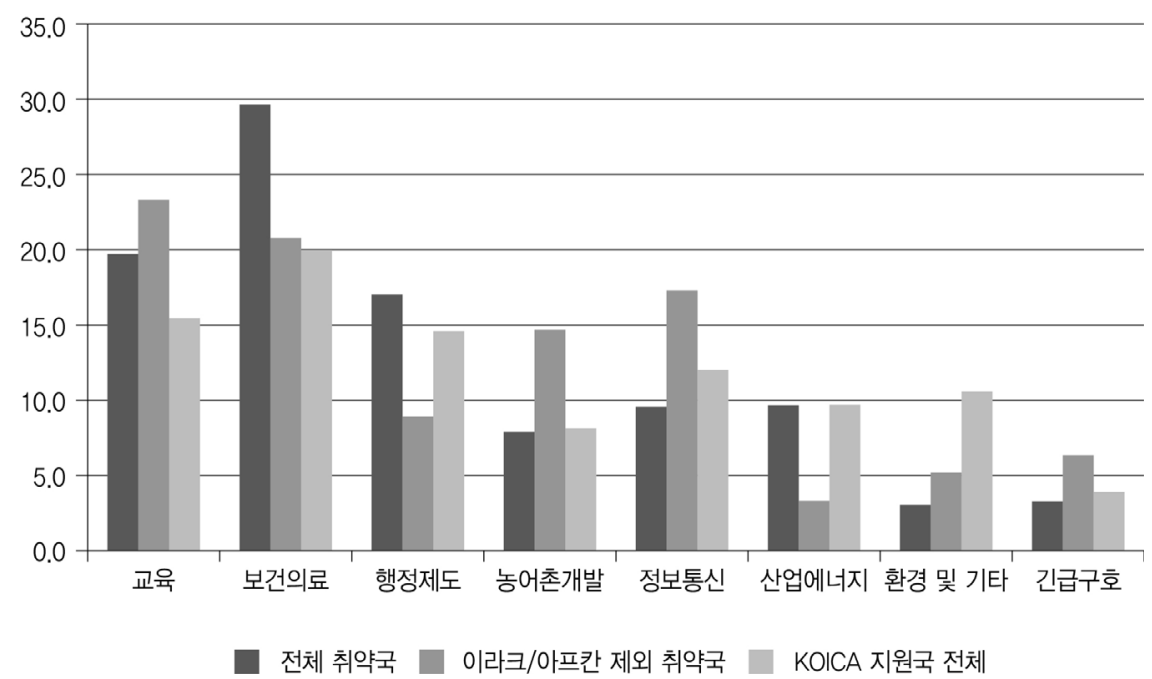

출처: 권혁주 외 (2010)

<그림 5>를 살펴보면, 산업에너지 분야에 대한 지원이 유독 적은 것이 눈에 띤다. 이라크, 아프간을 제외하면 긴급구호 분야보다도 적다.

우리는 분쟁국에 대한 지원이라고 하면 은연중에 난민에 대한 긴급구호나 식수, 식 량, 아동교육 등 인도주의적 지원만으로 대상을 한정하는 수가 많다. 그러나 2010년 작성된 '분쟁 및 취약국에 관한 딜리 선언(Dili Declaration)'은 인간안보확보, 평화구 축, 굿거버넌스 그리고 국제안보(global security)확대에 관한 지원 외에도, 분쟁 및 취 약국에서 평화구축 및 국가건설의 장애물 가운데 하나로 '수도와 일부 지역에 개발협 력이 집중되면서 지원에서 배제되는 지역(pockets of exclusion)의 출현'을 들고 있다. 더불어 '지속가능한 생계대책 마련, 고용 창출 및 천연자원의 효과적 관리를 포함한 포괄적 경제발전'을 발전목표 중 하나로 제시하고 있다.

한편, 공여자로서 우리 입장을 살펴보자. 공여금액이 상대적으로 적은 것은 차치하 고서라도, 분쟁 이후 정부구성 등 state-building 지원이나 정부기능의 정상화 및 행정 역량 강화 등 사업에 우리가 얼마나 차별성 있는 장점을 보유하고 있는가? 수원국은 우리에게 어떤 것을 원하고 있는가? 
우리가 가진 장점을 활용하여 우리 원조를 차별화하자는 원론적인 차원에서, 말리 에서 외국인직접투자와 원조기관 간 협조융자를 결합해서 추진했던 원당(原糖)공장 사업 내용을 <그림 $6>$ 과 같이 소개하고자 한다. 분쟁 발발로 인해 외국인 투자자가 투자계획을 철회하면서 무산되기는 했지만, 우리와 같이 원당을 전량 수입하는 입장 의 공여국과 말리처럼 농업기반이 있으나 제조업 기반이 허약한 수원국이 협력할 수 있는 아이디어다.

우리가 차별성을 가진 분야를 지원하는 것이 자칫 우리 이해관계를 수원국에 투사 한다는 오해와 비난을 받을 것을 두려워하기 보다는, 분쟁을 겪은 수원국이 진정으로 원하는 지원이 무엇인지를 더욱 고민하자고 제안한다.

<그림 6> 말리 원당공장 협조융자 사업구도

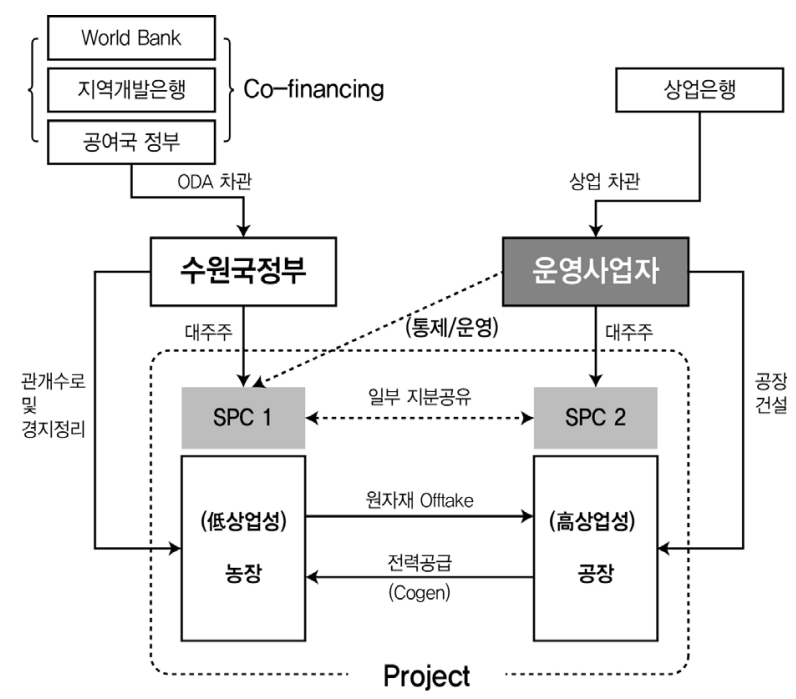

출처: 사업주 자료로 저자 작성 


\section{참고문헌}

강서미. 2010. KOICA의 취약국지원전략. 국제개발협력 2010년 3호. P. 66 76. 한국국제협력단

경제개발협력기금. 2011. 국가별지원사업_말리. www.edcfkorea.go.kr 권유경. 2014. 사하라이남 아프리카지역의 종족갈등과 빈곤. 국제개발협력 2014년 2호. P.177 197. 한국국제협력단

권혁주. 2010. 취약국가의 이해: INCAF와 국제협력 기구의 논의를 중심으로. 국제개발협력 2010년 3호. P.46 65. 한국국제협력단 권혁주, 이환성, 배재현. 2011. 한국 ODA 의 분쟁 및 취약국 지원방안. 한국 국제협력단

김정숙 외. 2011. 북아프리카지역에서의 부족집단 간 갈등양상에 관한 기초연 구: 마그레브지역의 베르베르족을 중심으로. 대외경제정책연구원 부산 세계개발원조총회. 2011. '효과적인 개발협력을 위한 부산 파트너십' 이욱헌. 2012. 분쟁지역에서의 국제개발협력. 인지제고사업 교육자료 이현. 2014. 테러리즘과 국제개발협력: '분쟁과 개발'의 맥락으로 본 테러리즘. 국제개발협력 2014년 3호. P.177 194. 한국국제협력단 폴 콜리어. 2010. 빈곤의 경제학. 류현 역. 살림출판사. 한국국제협력단. 2013. KOICA 연구 중기전략 : 2013-2017.

Collier, P. 2003. Breaking the conflict trap: Civil war and development policy. World Bank Publications.

Donor Conference for Development in Mali. 2013. Joint Chairs' Conclusion, International Donors Conference 'Together for a New Mali'. Brussels

Hannah Armstrong. 2013. Crisis in Mali: Root Causes and Long-Term Solutions. PeaceBrief 149

Oxfam. 2013. MALI: A NEW DEVELOPMENT CONTRACT What kind of aid is needed to end the crisis?. Oxfam Briefing Note (May 15, 2013) 
Oxfam. 2014. WHAT NEXT FOR MALI? Four priorities for better governance. Oxfam Briefing Note(February 5, 2014)

Republic of Mali. 2011. GROWTH AND POVERTY REDUCTION STRATEGY PAPER (GPRSP) 2012 2017

Republic of Mali. 2013. Plan for the Sustainable Recovery of Mali 2013-2014

www. diplomatie.gouv. fr

www. usaid.gov

제팡

www. crisisgroup. org

www.kida.re.kr/woww/

www. usip.org

제피장

www. unher. org

www. theguardian. com 